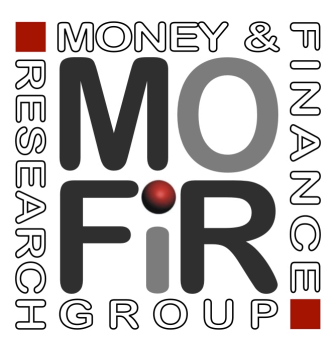

\title{
BANKS, REGIONS AND DEVELOPMENT AFTER THE CRISIS AND UNDER THE NEW REGULATORY SYSTEM
}

Pietro Alessandrini Michele Fratianni Luca Papi Alberto Zazzaro

Working paper no. 124

June 2016 


\title{
Banks, regions and development after the crisis and under the new regulatory system
}

\author{
Pietro Alessandrini \\ Università Politecnica delle Marche and MoFiR \\ Michele Fratianni \\ Indiana University, Università Politecnica delle Marche and MoFiR \\ Luca Papi \\ Università Politecnica delle Marche and MoFiR \\ Alberto Zazzaro \\ Università di Napoli Federico II, Università Politecnica delle Marche, MoFiR and \\ CSEF
}

\begin{abstract}
One of the most evident consequences of the Great Financial Crisis has been a rapid expansion of banking regulation. We argue that the burden of the new regulatory system is asymmetric, driving small banks to the "too-small-to-survive" zone, while reinforcing the "too-big-to-fail" protection for big banks. The asymmetric effect on banking structure produces related asymmetries on firms and regional economies, in light of the fact that small firms and peripheral regions are highly dependent on bank credit and need strategic proximity of banking structures. Finally, our review of the literature on different countries and on different periods of time, including the financial crisis years, suggests the importance of a differentiated banking model when firms and regions are heterogeneous. There is no obvious optimal size of bank.
\end{abstract}

JEL Classification: G01, G18, G21

Keywords: financial crisis, regulation, small banks, large banks, asymmetries, heterogeneity.

Pietro Alessandrini at p.alessandrini@univpm.it, Michele Fratianni at fratiann@indiana.edu, Luca Papi at 1.papi@univpm.it and Alberto Zazzaro at a.zazzaro@univpm.it. 


\section{Introduction}

There is broad agreement that four concomitant waves are at the root of the last financial crisis: monetary policy, credit, trust and bank regulation. These waves have swung from liquidity expansion to boost economic activity to money tightness to contain the risk of speculative bubbles, from credit boom to credit crunch, from expansive trust in counterparties to generalized distrust, from a liberal regulatory environment to reregulation that runs the risk of financial suppression. Furthermore, the four waves have interacted with one another and have reinforced their joint strength. As the effects of the crisis have settled, three main aspects of a new operative scenario in banking have emerged:

1. the end of the liberalization myth, which was adopted to improve the efficiency of banks and financial markets: years of deregulation had enhanced the rise of big universal banks, unanimously considered to have spread contagion in the crisis through the originate-and-distribute model;

2. the return to a growing regulatory system to forestall financial risks and to regain banking stability; and

3. the trend toward a higher diversification of funds available to productive firms, in the direction of reducing the share of pro-cyclical bank credit by increasing the flow of negotiable assets (bonds and shares) raised directly in the markets.

At this point, it is relevant to understand how and to what extent this new scenario will impact on the links among banks, regions and local development. Before the crisis, Alessandrini, Papi, and Zazzaro (2003) reviewed these connections along the following dimensions:

a. the effects of banking consolidation on both bank competition and credit conditions;

b. the effects of bank mergers and acquisitions on small firms' financing;

c. the role of local banks in financing local development; and

d. the effects of banking integration on regional development disparities.

Our purpose is to reconsider these issues in the light of the new operative scenario and of the main empirical results that have emerged in the last 15 years. To better focus on an historical perspective, we start our analysis by dedicating Section two of the chapter to a rapid excursus of the regulationderegulation pendulum that has been working from the Great Depression (GD) of the 1930s to the Great Financial Crisis (GFC). The main conclusion of this Section is that each phase of the pendulum has left an impact on the structure of the banking system and on the credit market. In the current situation, the re-regulation wave has put more emphasis than in the past on a complex system of controls to cover an extended range of risks of banking intermediation. The burden of such a stability, excluding the initial rescues, has been borne by banks, particularly European, with no adequate distinction relative to size, organizational structure, kind of intermediation, customer portfolio (i.e., 
relevance of small firms), and regional development. Our point of view is that the macro impact of this microprudential approach will produce asymmetric effects on the structure of the banking system. The tighter regime of controls and requirements stimulates bank consolidations, while penalizing in relative terms small local or community banks.

Section three questions whether greater integration of European financial markets is best served by further bank consolidation. The literature does not offer univocal answers on the links between bank structure and development. The financial crisis has contributed to the opacity of the empirical results, but it has also revealed the risks connected to financial deepening and overbanking. Section four reviews the empirical evidence on the relevance of banking geography in presence of an uneven playing field in which global and local banks compete in fostering local development and reducing regional disparities with different objectives and comparative advantages. The results demonstrate that one cannot arrive at a "best" model by contrasting global versus local banks. Section five draws main conclusions.

\section{The regulation-deregulation pendulum and banking structure}

Over the last eight decades, we have had two peaks of financial regulation, the first in the wake of the GD of the 1930s and the second after the GFC of 2008-2009. Between these two peaks we have experienced a long wave of deregulation that started in the 1980s and progressed in the 1990s. At the end of the GD the United States, having suffered a traumatic stock market crash and a series of debilitating banking crises, led the re-regulation movement: first by enacting the Glass-Steagall Act of 1933 that, not only established the Federal Deposit Insurance Corporation, but separated commercial banking from investment banking activity; and second by erecting a protective wall around commercial banks which were shielded by interest rate ceilings in the deposit market through interest rate (so-called Regulation Q). The separation of commercial banking from investment banking was designed to end the model of universal banking that legislators believed was responsible for stock market speculation. ${ }^{1}$ Re-regulation occurred also in other countries, albeit in different form and with different tempo. For example, Fascist Italy, having gone through three waves of industrial and banking crises in the Twenties and early Thirties, opted to protect bank depositors, not through a deposit insurance institution, but by nationalizing the bulk of the Italian banking system and transforming all banking activities as "public law" activities, in essence making banking the business of the State (Fratianni and Spinelli 2001: 316321). Despite these differences, the Italian Banking Law of 1936 shared with the Glass-Steagall Act the objective of functional separation of the banking system: deposit-creating banks were restricted to extend relatively short loans, while leaving longer-term loans to special credit institutions that obtained

\footnotetext{
1 The evidence is far from clear that securities affiliates of commercial banks engaged in "excessive" speculative activities (White 1986).
} 
financing from the capital market. In this way, maturity transformation was minimized. In sum, postGD regulation was designed to alter banking structure and create a safety net around banking. This model was firmly in place through the end of the Bretton Woods system.

The 1980s brought a more liberal climate of capital flows and deregulation of deposit and credit markets. Cracks began to show in the regulatory apparatus both at the national and international level. The US Savings and Loan crisis of the 1980s was a classic case of national regulatory forbearance; it was followed by an even greater regulatory failure in Japan in the 1990s. Safety nets were subsidizing risk more than reducing it, while banks and regulatory agencies were following their own wishful gambles for resurrection strategies. It was also clear that lower regulation countries, like Japan, engaged in unfair competition with higher regulation countries (Fratianni and Pattison 2002). Basel I (1988) was born out of these concerns. It was an accord on minimum capital requirements computed by assigning arbitrary, simple and mechanistic weights to different bank asset categories. Bank safety was the essential reason underlying higher capital requirements. Furthermore, if the average cost of capital were to be insensitive to leverage, as implied by Modigliani and Miller (1958), higher capital requirements would not affect the cost of bank lending. But serious doubts exist that the capital structure irrelevance theorem may hold for banks (Cline 2015). At any rate, Basel II (2004) rectified some of the deficiencies of Basel I, covered other important aspects of risk, and introduced requirements on information disclosure on capital and risk management. The expansion and the internationalization of regulation and supervision was accompanied by an expansion of the safety net. Central banks became fully committed to provide, in a crisis emergency, liquidity and deposit insurance systems proliferated. The too-big-to-fail (TBTF) principle was officially enshrined in the United States in September of 1984, following the bailout of the Continental Illinois National Bank.

The first signs that the post-GD regulatory apparatus was coming to an end also appeared in the 1980s with the dismantling of Regulation Q in the United States and Big Bang in the United Kingdom. The weakening of this apparatus correlates with the resurgence of the universal banking model. In Italy, the Amato Law of 1990 signaled that the functional specialization prescribed by the Banking Law of 1936 had short life left. With the Second European banking directive of 1992 and the New Banking Law of 1993 (Testo Unico Bancario) the universal banking model received the official imprimatur. The United States followed suit, first by allowing two large mergers, the first of Morgan Stanley (an investment bank) with Dean Witter Reynold (a brokerage firm) and Discover (a credit card company) in 1997, and the second between Travelers Insurance with Citicorp in 1998. In 1999, the Glass-Stegall Act was replaced by the Gram-Leach-Bliley Act, which reintroduced the universal banking model. By removing barriers between commercial banking, investment banking and insurance, the new deregulation, set in an environment of liberalized capital flows, facilitated the growth of large, complex, interconnected, and international banks. From 1999 to 2008, total assets of the world's largest banks 
rose at least by a factor of two and in some cases by a factor of four (Laeven et al. 2014: Figure 1). Big became bigger and with it grew the relevance of TBTF. ${ }^{2}$

Under the pressure of the crisis, Basel III (2010-11) emerged as a much more muscular version of Basel II in terms of capital requirements. It also introduced non-credit risk based requirements such as minimum leverage and liquidity ratios. Basel III is actually an ongoing process that produces a constant flow of new norms and clarifying documents. ${ }^{3}$ But the one feature that really stands out in Basel III is complexity (Masera 2015: Figures 1-4). Complexity goes beyond the enormous number of pages detailing norms and interpretation. It is measured in terms of data, analytics, implementation and reporting requirements. ${ }^{4}$ The basic issue at stake is whether complex systems are better handled by complex controls or simple controls. Judged in terms of interaction alone, complex controls are at a disadvantage relative to simple controls. Implementation and compliance costs are another strike against complexity. Furthermore, while Basel III defines a forest of risk definitions, it ignores that ultimately risk is determined by the interaction of a complex system with complex controls (Caprio 2013). Take as an example the zero weight on holdings of government securities. This induces banks to re-allocate portfolios in favor of government debt and governments to accommodate the higher demand, a process that alters the nature of risk. In a crisis, a big wedge develops between the market perception of risk and the definition of risk set by the regulators. This wedge encourages simultaneous sales by all banks, as it happened with Greek bonds during the sovereign debt crisis. The point is that risk changes and that a Gosplan-type regulator works "no better for bankers than it did for tractors" (Haldane 2011: 10).

Going back to our theme of banking structure, Basel III treats all banks virtually the same. ${ }^{5}$ This uniformity affects unfavorably the smaller local or community banks that are an important feature of many banking systems, including the United States and several European countries, Italy included. The uniformity of regulation penalizes local banks relative to larger banks because the implementation of complex regulation is to a large extent a fixed cost (Koch 2013: Chart 4). But there is a second disadvantage falling on smaller banks: the subsidy that large banks may still receive from the possibility that the capital surcharge may not be adequate to prevent being rescued by governments. Without a regulatory correction, small banks are at risk of disappearing, an issue that is hotly debated in the

\footnotetext{
2 Recently, the Financial Stability Board has identified 30 mega banks as "global systematically important banks" (G-SIBs). As of 2014, the 30 G-SIBs held assets valued at approximately $\$ 47$ trillion and capital valued at $\$ 2.5$ trillion (Persaud 2014:2).

${ }^{3}$ For example, the most recent concern of the Basel Committee for Bank Supervision is how to treat differentially a group of $30 \mathrm{G}$-SIBs so as to compensate for the contingent subsidy implied in being TBTF; for the evolution of the capital surcharge on the mega banks refer to Financial Stability Board $(2014,2015)$ and for estimate of the size of the subsidy earned by TBTF banks refer to Siegert and Willison (2015).

${ }^{4}$ Haldane (2011:2-3) offers a simple metric of such complexity: “... using an advanced internal set of models to calibrate capital...number of risk buckets has increased from around seven under Basel I...to, on a conservative estimate, over 200,000 under Basel II...to over 200 million [under Basel III].”

5 Except the 30 G-SIBs.
} 
United States, which has already implemented a dual-regulatory system, one that is applicable to very large banks (Advanced Approaches Banks) and another to community banks (Fratianni 2015). The latter face smaller risk-weighted capital ratios than the former and are exempt from the countercyclical capital buffer, supplementary leverage ratio, and credit valuation adjustments requirements (Hunter 2015). Furthermore, community banks in the United States are subject to lighter supervision than applicable to large banks and are exempt from stress testing and capital planning requirements (Yellen 2014). In contrast, the EU application of Basel III does not make any substantial distinction between large and local banks 6 .

To conclude, regulation impacts not only risk and profitability of the banking system as a whole but also its structure. The last wave of regulation is relatively unfriendly to local banks, reflecting the position of regulators, especially European, that a consolidation of the banking system can lower systemic risk. American regulators, unlike their European counterparts, appear to be convinced that variety of organizational forms in banking is worth preserving.

\section{A new wave of banking consolidation?}

In the renewed regulatory environment, cross-border mergers and acquisitions (M\&As) in the euro area (EA) confirm the trend in number and value of transactions that has prevailed since the global financial crisis of 2007-2009. In fact, from December 2013 to December 2014 the number of EA credit institutions has decreased by 8 per cent, from 5347 to 4910, a reduction that is similar to that occurred during the entire previous five years (Figure 1). This trend is likely to persist in the future.

At the same time, banks are changing their spatial organizational structure, by reducing the number of branches and increasing the use of impersonal tools to manage deposit and loan relationships, such as e-banking and internet-based platforms (Petersen and Rajan 2002). In Europe, the number of branches peaked in 2009 with 186,255; then the trend has been reversed: in 2014 there were 159,396 branches. The phenomenon is even more evident if we consider the dynamics of the ratio between population and number of branches (Figure 1). In contrast, the penetration of online banking has almost doubled from 2007 to 2015, reaching 46 per cent of population ${ }^{7}$, even if this percentage is extremely variable across EU countries, from 90 per cent in Norway, to 26 per cent in Italy and 5 per cent in Bulgaria, Macedonia and Romania).

\footnotetext{
${ }^{6}$ In fact, with the exception of the global systematically important banks, the European regulatory approach envisages a sort of one-size-fits-all regulation framework relegating the implementation of the principle of proportionality basically to a different frequency of the supervisory engagement for the various size categories of banks

7 Figures on online banking penetration in European countries are drawn from Statista at statista.com/222286/onlinebanking-penetration-in-leading-european countries.
} 


\section{Figure 1 Structural Banking Indicators \\ (Euro Area)}

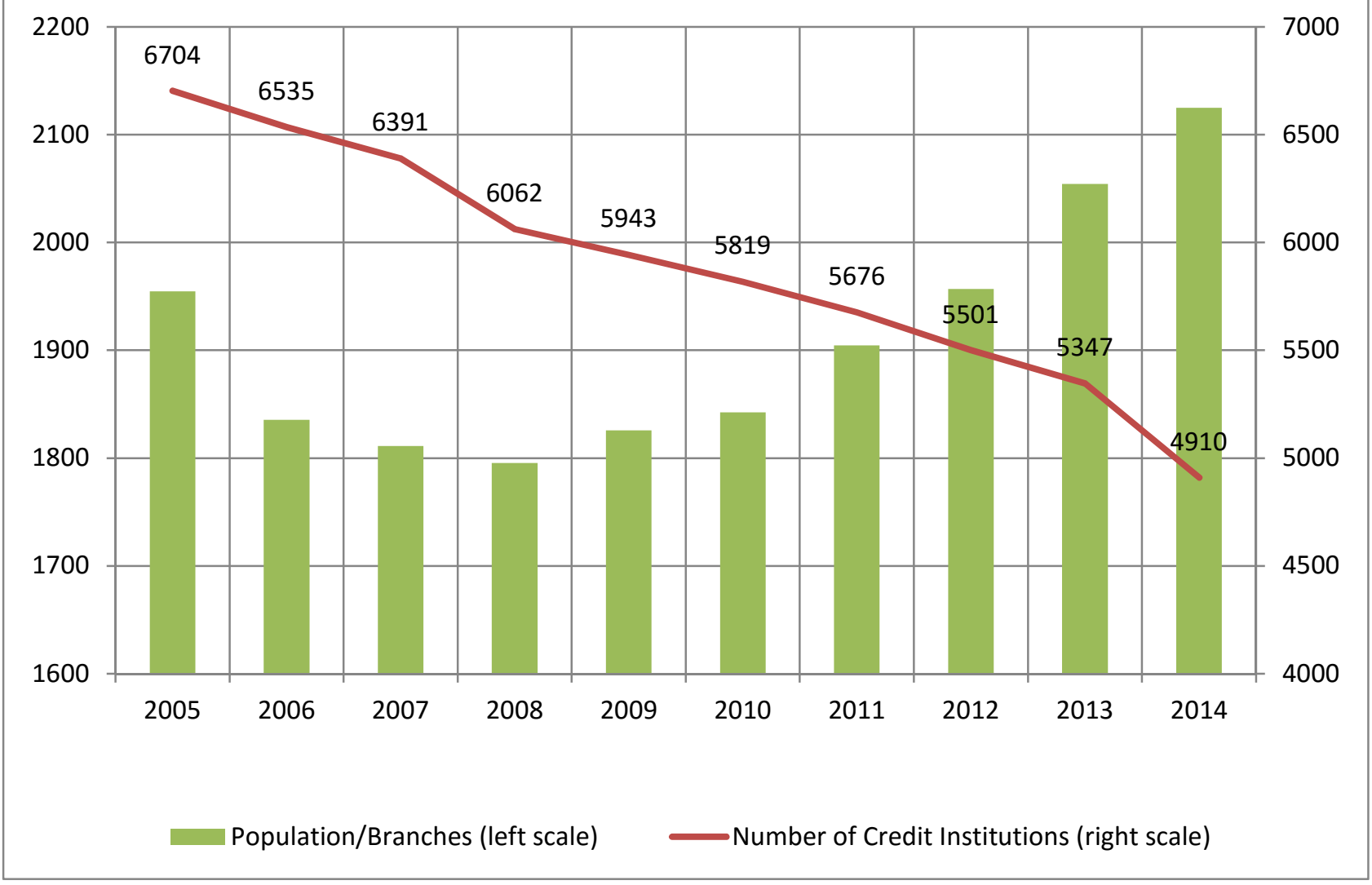

These changes in the European banking structure raise new and old questions. Does Europe need further banking consolidation? Does increasing financial market integration require a new wave of bank mergers and acquisitions? What is the likely impact of this new wave of banking M\&As on the growth of peripheral European regions and access to credit for small, local enterprises and households?

These are complex questions to which it is difficult to give clear, univocal answers. Much will depend on what banks will be involved in the deals, how these operations will be designed and conducted and how the emerging larger, pan-European banking organizations will be actually managed. However, the experience of the Nineties and the empirical evidence accumulated in the last twenty years on the organizational structure and geographical distribution of banks should help to inform the political debate and prevent further imbalances in the EA.

\subsection{Banks and development}

For forty years after the publication of Goldsmith's (1969) book on Financial structure and development, the empirical literature has been engaged in identifying the causal direction between financial deepening 
and economic growth. Hundreds of papers have been devoted to establish whether banks are "the headquarters of the capitalist system" where "the settlement of plans for further development is decided” (Schumpeter 1934: 126) or “...enterprise leads finance follow” (Robinson 1952: 86).

The vast literature on banks and development, comprehensively reviewed before the crisis by Levine (2007), leads to three broad generalizations:

(i) countries with more finance, efficient banks and well-functioning financial markets grow faster;

(ii) causality goes from finance to economic growth or, at the very least, is bi-directional; and

(iii) financial systems tend to ease the financing constraints that impede innovation and interfere with efficient inter-sectoral resource allocations in the economy rather than induce capital accumulation.

The dramatic GFC has thrown serious doubts on these optimistic conclusions about the financegrowth nexus. Many scholars seem to rediscover the admonitions of Hyman Minsky and James Tobin on the instability and "unproductivity" of financial markets and the risks of an over-financialization and over-bancarization of the economy. The risk is that we are "throwing more and more of our resources, including the cream of our youth, into financial activities remote from production of goods and services, into activities that generate high private rewards disproportionate to their social productivity" (Tobin 1984: 14).

In this perspective, an increasing number of papers have documented that financial deepening is not always beneficial for economic growth and that economies can be overbanked, that is devoting too many resources to a good thing. Rioja and Valev (2004), for example, find that an increase of financial depth has a positive and strong impact on the rate of growth of countries that are at an intermediate level of financial depth, while it has small or no effects in countries at low and high levels of financial depth. In a similar vein, Rousseau and Wachtel (2011) show that the positive contribution of finance to economic growth has disappeared after the Nineties. Moreover Easterly et al. (2000), Arcand et al. (2012), Cecchetti and Kharroubi (2012), Law and Singh (2014), among others, have documented that the effect of additional lending on GDP growth rate and volatility become negative when the ratio between private-sector credit and GDP exceeds 90-100 per cent (the vanishing effect). Consistent with this indication, Cournède and Denk (2014) find that in OECD countries financial development is negatively associated with GDP, while Pagano and Pica (2012) show that in these countries financial development has no differential impact on the rate of growth of those industrial sectors that are more heavily dependent on external finance. Finally, Ductor and Grechyna (2013) and Cecchetti and Kharroubi (2015) look at the relationship between financial growth and real growth. The former show that in countries where the financial sector grows much more rapidly than industrial sectors the contribution of a further financial development to real GDP growth is negative. Cecchetti and 
Kharroubi (2015) find that higher financial growth unambiguously decreases economic growth and in particular those industrial sectors that make greater use of intangible assets and R\&D.

\subsection{Overbanking in Europe}

Based on these and other findings, a recent report produced by the Advisory Scientific Committee ${ }^{8}$ of the European Systemic Risk Board (2014) has firmly concluded that Europe is overbanked. In particular, the Committee point out that in Europe bank loans have exceeded 100 per cent of GDP, while in the United States, but also in Japan, is considerably lower (40 and 80 per cent, respectively). A similar picture emerges if we compare bank loans to net household wealth. At the same time, the banking system is significantly more concentrated in Europe than in the USA: the assets of the largest 20 US banks account for about 100 per cent of GDP, with an increase of 61 per cent between 1996 and 2012, while in the EU total assets of the largest 20 banks in 2012 were about 170 per cent of GDP, 139 per cent higher than in 1996. These two facts lead the authors of the report to conclude that "the large size of the EU banking system and the size of largest banks are two related phenomena $\ldots$ are two sides of the same coin" (ESRB 2014:7).

One of the reason that explains the steep and rapid growth of the European banking system, the report continues, is the deep links between banks and politics, and the "banking nationalism" bias of EU national governments during the initial stages of the European Monetary Union. This resulted in promoting national champions, laxer bank supervision and greater state support to banks, all of which led to oversizing domestic banking systems and the European banking industry as a whole.

However, paradoxical as it may seem, the favorable attention that banking nationalism has encountered among politicians and regulators, besides reflecting lobbying by domestic banks and their political connections, comes from a widely shared opinion among scholars and observers in the Nineties of the supremacy of universal and global banking players in efficiency and innovation; see also our Section two. As it was commonly argued at that time, deregulation, advancements in information and communication technology and financial innovations would have made banking activity ever more transaction oriented, by including a wide-range of non-traditional financial products and arm's length lending technologies. In this new, more competitive environment, traditional commercial and local banks would have been crowded-out by few global banks expanding geographically and supplying standardized financial products without suffering a permanent disadvantage in making loans to small local firms.

Admittedly, the more thoughtful scholars recognized that organizational diseconomies in global banking, emanating from information collection in many different local realities, could lead to a

\footnotetext{
8 The Advisory Scientific Committee was chaired by Marco Pagano and assisted by Sam Langfield, with the participation of V. Acharya, A. Boot, M. Brunnermeier, C. Buch, M. Hellwig, A. Sapir and L. van den Burg.
} 
temporary decline in lending to SMEs, especially in peripheral economies. This decline would have disappeared, however, as soon as global, out-of-region banks adapted to the needs of the new local areas and local banks adjusted to the new competitive pressure of global banks. At this stage, a supranational and fully integrated banking system would have flourished, wiping out the constraints of distances and replacing the 'geography of banks' with the 'geography of financial flows' (O'Brien 1992).

It was such a common belief and the fear of being only passive spectators of the process of financial integration that led EU governments and central banks to encourage the process of consolidation of national banking systems by providing implicit support to domestic banks considered better equipped for serving as "national champions" and for withstanding the competition of European global banks in a financially integrated area (Alessandrini et al. 2009a). This would also come at the expense of a great reduction in the functional and strategic autonomy of banking systems of large, subnational peripheral regions. In Italy, for example, it was this uneven stance toward "national" and "regional" champions that may explain the support that Treasury and Bank of Italy gave to the acquisitions of Banco di Napoli and other Southern banks in distress by banks of the Centre-North, thought to be well managed to survive competition from European rivals (Giannola 2002; Zazzaro 2006). $\cdot 9$

The mixed rhetoric of national champions in integrated competitive markets, and the stark contrast between the goal of keeping national banking autonomy and its irrelevance at the regional level, appear to re-occur at the EA level, under the impact of the asymmetric burden of regulation on large vs small banks; and the added risk of producing financial marginalization in some member countries. It may be time to evaluate the expected effects of the new wave of cross-border M\&As in Europe by balancing the benefits of having more efficient and globalized banks with the costs of excessive bancarization and the negative externalities due to concentration of bank headquarters in few financial centers.

\section{Global banks, local banks and distances in regional development}

A growing empirical evidence suggests that liquidity management and lending activity of local branches and subsidiaries are influenced by the organizational complexity of their banking institutions (bank holding companies, banking groups or stand-alone banks), and that local branches and subsidiaries of global banks allocate resources differently from stand-alone banks having their strategic center in the same region.

\footnotetext{
9 "It goes without saying - is noted in a report of the Bank of Italy on the Southern banking system that had great resonance in the early Nineties, well before the Southern banks were officially declared bankrupt and their capital was written off - that mergers and acquisitions lead to improved financial and productive combinations when they are conducted within a well defined and coherent strategic context, and when at least one of the two parties involved in the deal contributes to increase the economic and financial stability and the managerial efficiency of the new bank. The need to satisfy this basic postulate leads to identify the possibility of mergers and acquisitions between Southern and Central-Northern banks" (Galli and Onado 1990:48-49, our translation from the Italian edition).
} 
Starting from Stein (2002), the literature has emphasized that organizational complexity and geographical and cultural distance between the different hierarchical layers of a banking organization have an effect on information production, lending technologies and credit allocation. The broad idea is that information asymmetries and agency costs inside a bank organization lead to hierarchical and functional distance separating peripheral structures of the bank from its headquarters, which in turn impact on bank lending policy, bank officers' behavior and access to credit for local firms (Alessandrini et al. 2005). Information about local enterprises, it is argued, is mainly soft and embedded in the local economy and society, and can be effectively gathered only by loan officers working and living in the same neighborhoods as borrowers. As a result, information about borrowers' creditworthiness is largely asymmetric within the bank organization and this provides local loan officers with the opportunity to take advantage of an informational rent at their own private benefit.

In such cases, parent banks find themselves coping with an organizational trade-off between delegation (decentralization) and control (hierarchy) of lending activity, giving rise to significant managerial diseconomies (Aghion and Tirole 1997; Dessein 2002; Alonso et al. 2008). Accordingly, global banks have to design costly loan reviews, officers' rotation and incentive pay systems to mitigate moral hazard behavior of local officers (Udell 1989; Hertzberg et al. 2010; Uchida et al. 2012). In this setting, functionally distant banks may find it optimal to limit their lending to informationally opaque borrowers. In addition, to the extent that local management of these banks is typically made up of temporary officers, whose salary and career opportunities depend on the current profitability of the office, local loan officers may have incentive to invest in short-term and hard-information-based projects, diverting time and effort from producing and using soft information difficult to communicate across hierarchical layers.

Finally, the geographical distance of the bank's strategic and decisional centers from the operating region tends to reduce social embedment of local branches and subsidiaries, thus reducing the "sensitivity" of the lending policy to the needs of the local economy and to the lobbying effort of local society. In fact, internal capital budgeting decisions and liquidity flows across bank branches reflect not only on the local lending opportunities, but are also the result of corporate politics and the economic, social and cultural importance that the local economy and society have at the bank headquarters where CEOs and senior managers live and work and where budgeting decisions are taken (Meyer et al. 1992; Scharfstein and Stein 2000; Carlin et al. 2006; Landier et al. 2009). According to this view, we can reasonably expect that the impact of functional distance on the behavior of local branches and subsidiaries is especially strong in less developed, peripheral regions whose economic, social and cultural environment is very distant from that prevailing in the headquarters of parent banks.

In the rest of this section we selectively review the literature on the importance of banking organization by focusing on three related but distinct aspects: 
(i) the effects of bank size and banking consolidation on small business lending;

(ii) the effects of organizational complexity and functional distance on credit allocation and financial shock transmissions to peripheral regions; and

(iii) the role of small, local banks in promoting economic growth in local economies.

\subsection{Bank size, consolidation in banking industry and small business lending}

In the Nineties a great number of studies have analyzed the effects of bank size and consolidation on

small business lending. 10 Overall, this literature shows that large banks tend to allocate a smaller share of their assets to small business lending and to rely more on hard-information lending criteria than small, local banks (Berger et al. 1995, 2005; Cole and Goldberg, 2004; Scott 2004; Uchida et al. 2012; Ogura and Uchida 2014). This is to confirm that large banks are at a competitive advantage in supplying standardized products and underwriting loans with large companies. However, other studies have documented that, at least in the United States, access to credit by small firms is broadly unrelated to the share of large banks in the local credit market (Strahan and Weston 1998; Avery and Samolyk 2004; Berger et al. 2007; Berger and Black 2011). This result is consistent with the hypothesis that it is the share, but not necessarily the total amount, of loans to small firms that decreases with bank size and that the reaction of other banks operating in the same market allows to cover the market segments left uncovered by large banks.

In view of these findings, M\&As should not necessarily worsen the conditions (price and quantities) of access to credit by small businesses. Actually, the extant evidence confirms that the effects of bank consolidation on small business lending are not univocal, and depend on the type of institutions involved in the deals and on the economic conditions of the area where the consolidated/affiliated bank operates. Specifically, when two medium-large banks consolidate or when a large bank incorporates a small bank, loans to small firms tend to decrease significantly (Peek and Rosengren 1998; Strahan and Weston 1998). By contrast, M\&As involving small banks usually lead to a bigger share of loans to small firms. In addition, loans to local small firms from affiliated banks are more responsive to local market conditions than loans from stand-alone banks, and loan growth of affiliated banks is positively correlated to the parent bank's cash flow and negatively correlated with loan growth of the group's other affiliated banks (Houston, James and Marcus 1997; Houston and James 1998).

Similar heterogeneous results emerge for Italy. Focarelli et al. (2002) find that, three years after a M\&A transaction, banks involved tend to reduce small business lending and reduce non-performing loans. In other words, banks implement a cherry-picking strategy by shifting lending towards larger but less risky borrowers. In a similar vein, Bonaccorsi and Gobbi (2001), employing data from Italian

\footnotetext{
${ }^{10}$ For an extensive review of this literature see Berger and Udell (1998) and Berger et al. (1999).
} 
provinces, show that the higher the number of bank M\&As the smaller is the average loan amount extended to small firms. At the firm level, Bonaccorsi e Gobbi (2007) find that firm's total credit is negatively associated with the share of their credit from banks involved in M\&As, although the decline is short run in nature and tends to be absorbed after three years.

Similarly, Sapienza (2002), using micro data of bank-firm relationship, shows that merged banks tend to break off lending relations with small businesses - no matter the level of firms' debt and profitmore often than those other banks not involved in a M\&A transaction. As of the cost of credit, the same study finds interest rates tend to decrease only if the M\&A involves small banks. Alessandrini et al. (2005) and Alessandrini et al. (2008) distinguish, in the Italian case, between M\&As among banks headquartered in the same region and M\&As among banks with headquarters in different regions. Alessandrini et al. (2005) find that, contrary to what had been observed for acquisitions within the Central-Northern regions, the performance of Southern banks belonging to a Central-Northern banking group is still lower than that of Southern stand-alone banks, even three years after acquisition. In particular, size, market power, capital adequacy and local presence being equal, those Southern banks which are part of a Central-Northern banking group tend to lend less to small businesses, to have a worse credit quality and a lower profitability when compared to stand-alone banks. Alessandrini, et al. (2008) analyze the Italian experience with the restructuring asset portfolio strategies following bank acquisitions. At the national level, they find evidence of an asset cleaning strategy, in which the acquiring bank makes a clean sweep of all non performing loans in the portfolio of the acquired bank without modifying its composition in terms of loans and borrowers. On the contrary, the authors show that when the acquired banks are located in economic backward Southern Italian regions, the acquiring bank permanently changes the portfolio allocation of the acquired bank reducing loans to small businesses and increasing loans to large firms. However, the changes in the asset composition did not improve bank profitability, suggesting that those changes were not only related to the inefficiencies of the acquired banks, but also to the changes in the optimal asset structure following the acquisition and the respective strategies carried out by the new acquiring banking group.

Obviously, decrease in lending to small firms is welfare reducing only to the extent that this determines a cut in valuable investments. Otherwise, we would only be faced with the termination of inefficient credit lines (Berger, Kashyap and Scalise 1995). Unfortunately, in this respect the available evidence is scarce and even more inconclusive. However, the facts that loans to small firms from incumbent rival banks increase (Berger et al. 1998), that the higher probability of small borrowers being dropped by the consolidated bank is independent of borrower quality (Sapienza 2002; Degryse et al. 2011) and that returns of target banks, especially in the case of out-of-market acquisitions, do not always increase (Alessandrini et al. 2008) suggest that the reduction in small business lending does not simply reflect previous loan misallocation by the target bank, but rather it might be evidence of possible 
welfare losses.

\subsection{Organizational complexity, functional distance and credit allocation}

Consolidation processes have usually gone along with a concentration of bank headquarters and strategic functions in few financial centers. This has greatly increased the complexity of the banking organization and the functional distance between the locus of control of the banks' lending strategy from local branches and local economy where lending relationships originate and develop, with the effect of exacerbating agency costs and home biases and adversely influencing the availability of credit to local firms.

The empirical literature offers many consistent results supporting the importance of agency costs and home bias in geographically dispersed bank organizations. Overall, there is robust evidence for developed and developing countries that branches and subsidiaries of functionally distant banks tend to be less efficient (Berger and DeYoung 2006) and shy away from small business lending and softinformation-based credit relationships (Mian 2006; DeYoung et al. 2008). In addition, hierarchical and geographically dispersed banks are proven to make stronger use of transactional lending technologies (Berger et al. 2005, Uchida et al. 2008). In particular, Liberti and Mian (2009) consider loans to large companies from a multinational bank in Argentina and document that the sensitivity of the approved loan amount to soft (hard) information is negatively (positively) associated with the geographical distance between the branch at which the loan originates and the loan approving bank office. Filomeni et al. (2016) analyze credit-score lending to medium-large enterprises from a multinational European bank and find that the probability that loan officers responsible for the scoring procedure use their subjective knowledge by overriding the statistical score tend to decrease with their distance from the bank headquarters. In addition, they show that, credit scoring being equal, loans originated at distant branches and approved at the bank headquarters are granted in a significant lower amount.

Consistent with the hypothesis that distant banks are less equipped to provide loans to opaque borrowers and process/use soft information, a number of studies show that firms located in regions disproportionally populated by functionally distant banks tend to have less access to credit (Detragiache et al. 2008; Alessandrini et al. 2009; Gormley 2010; Claessens and Van Horen 2014), a lower capacity to maintain a long-lasting bank relationship (Presbitero et al. 2011) and a lower propensity to innovate (Alessandrini et al. 2010).

The negative impact of functional distance on bank-firm relationships gets broad confirmation for the global crisis period. Specifically, after the Lehman collapse Italian firms borrowing from banks having their headquarters and branches far from the location where firms are headquartered paid on average higher interest rates (Gambacorta and Mistrulli 2014) and obtained lower amounts of credit (Gobbi and Sette 2015). At the market level, Presbitero et al. (2014) document that Italian firms 
headquartered in provinces populated by branches of banks headquartered in other far provinces are more likely to have experienced a credit crunch in the quarters after the Lehman collapse. Popov and Udell (2012) find similar results for the case of East European countries where firms in localities populated by foreign banks were more likely to be credit constrained during the early phases of the global crisis.

The existence of "home biases" in credit allocation is also well documented by the literature on syndicated loans and the functioning of banks' internal capital market. A number of recent contributions have found that global, multimarket banks (multinational or nationwide) exacerbate the transmission of financial shocks across regions. Specifically, these studies show that global banks experiencing a liquidity shock utilize the internal capital market to move funds from peripheral to their central markets. In other words, they seem to follow a sort of geographical pecking order which penalizes locations that are at a greater distance from the parents' headquarters, or that are not at the core of their lending activity, ${ }^{11}$ and by limiting access to credit to local firms when the local economy growth rate slows down. 12

This seems to have had great importance during the great crisis, when a "flight-to-home" effect is responsible for the decline of the banks' lending exposure to firms headquartered farther away from bank headquarters and the restriction in access to credit suffered by firms located in regions whose banking system is functionally distant from those regions. For example, Giannetti and Laeven (2011) find that the home bias in syndicated loans (measured by the share of syndicated loans to firms in the bank's home country) significantly increases if the home country of the bank experiences a banking crisis. In a similar vein, De Haas and Van Horen (2013) show that after the Lehman collapse global banks contracted more their cross-border exposure in countries geographically far from their headquarters, while Popov and Udell (2012) find that the negative impact of presence of foreign banks on access to credit for local firms is significantly higher when these banks or their parents experience a liquidity shock at home. Finally, Presbitero et al. (2014) provide evidence that the credit crunch occurred in Italy after the Lehman collapse has been also driven by a home bias effect in which functionally distant branches have reduced their lending in the region independently of the quality of local firms.

\subsection{Local banks and local development}

While there is clear empirical evidence of the differences between small and large banks in the structure of their assets and liabilities and in lending technologies, the evidence about the role of small, local

\footnotetext{
11 Among the others, see Peek and Rosengren (1997, 2000), Cetorelli and Goldberg (2012a, 2012b), Imai and Takarabe (2011), Schnabl (2012), Giannetti and Yafeh (2012), Berrospide et al. (2013); Dekle and Lee (2015).

12 See Campello (2002) and Cremers et al. (2010).
} 
banks in the local economic growth is scarcer and less clear. With regard to Italy, Ferri and Mattesini (1997) and Cosci and Mattesini (1997) document that the growth rate of value added at the provincial level is positively associated with share of local branches owned by cooperative banks. In the same vein, Lucchetti et al. (2001) find that the ratio between cooperative banks' loans and total loans at the regional level is significantly correlated with regional economic growth even after controlling for the efficiency of the local banking system and the share of loans going to the private sector. The positive impact of cooperative banks on regional economic growth is confirmed by Usai and Vannini (2005). In contrast, Angelini et al. (1997) find that at the municipal level the presence of cooperative banks has no significant impact on the variation of the rate of unemployment.

With regard to the US economy, Collender and Shaffer (2003) do not find any clear evidence of local banks influencing short- and long-term GDP growth rates of local economies (identified by the so-called metropolitan statistical areas and nonmetropolitan counties) differently from the out-ofmarket banks, while Jayaratne and Strahan (1996) find that the rate of growth of US states significantly increased in the years following the bank branch deregulation and the removal of state branching restrictions.

Recently Hakenes et al. (2015) have reconsidered the impact of small banks on economic growth looking at the case of Germany. In particular, they find evidence of a positive effect of the presence of small local banks (measured by the share of branches in the region belonging to saving and cooperative banks) on the growth in new business registrations, especially in less developed regions. Contrasting results about the role of local banks during the recent crisis have been found in the case of Italy. According to Demma (2015), over the period 2005-2012, the deterioration of credit quality has been less for local banks compared to non-local banks, after controlling for the credit demand and bank characteristics. More recently, Stefani et al (2016) show how Italian local banks increased their presence on local markets in terms of branches and loans during the seven years between 2007 and 2014 . However, the quality of their credit worsened markedly showing how the local banks' lending activity can be prone to severe risks, which in some cases might even outweigh the benefits of customer proximity. Finally, at the cross-country level, Berger et al. (2004) analyze the impact of the presence and efficiency of community banks on GDP growth rates of 49 developed and developing countries in the period 1993-2000, documenting a positive and significant relation.

\section{Final remarks}

One of the most evident consequences of the GFC has been the rapid expansion of banking regulation. Historically, the regulation-deregulation pendulum swings are affected by two forces: efficiency and stability. In crisis periods, stability goal prevails on efficiency. The opposite happens in periods of market stability and growth. It is clear that the era of deregulation, and the efficiency that came with it, is way behind us. The effects of liberalization are well known. Banks expand activities and instruments 
and develop new markets. Wider diversification yields obvious advantages, as it is evidenced by the growth of large multinational banks operating worldwide. But with the advantages come higher risks that are inherent with the flow of innovations. Examples of innovation are the originate-to-distribute banking model, the growth of shadow banking, the creation of complex and difficult-to-understand products, and rising interconnectedness. As banks become larger, their potential to do damage to the economy rises and so does the cost of no action should the large bank fail. Big banks are protected institutions by the "too-big-to-fail" umbrella.

During the GFC the authorities have reset their preferences swinging back to approximately the position that existed soon after the Great Depression. The adopted regulatory system is a constant flow of rules that raises an already awesome and complex stock of controls and supervision. This ongoing process has started to curb the effects of the crisis, but has created new targets justified by the potential risk of new crises. The implications are not minor and seem not to be yet fully appreciated. We have argued that the burden of the new regulation system is asymmetric and also contradictory to stated goals.

The main asymmetry concerns the structure of the banking system. First of all, higher costs are incurred by banks to meet the new regulatory prescriptions, such as the costs to set up and maintain organizational structures for internal audit, regulatory compliance, risk management, internal reporting to the board and external reporting to authorities and stakeholders. The second feature is the complexity of the new regulation, which is not only quantitative (that is, the actual number of pages contained in the regulatory documents). Complexity can also be measured in terms of the difficulty to interpret norms (that is, opaqueness). Banks meet qualitative complexity by hiring and training people with specialized skills or by paying external consultants. Since regulation is as much a flow as it is a stock, banks must meet the new challenges in a dynamic way. Given that a large part of meeting regulation is a fixed cost, its burden falls proportionally more on small, local banks than large banks. While this asymmetric burden is recognized and in part corrected in the United States, ${ }^{13}$ it is instead almost ignored in the European Union, where the "one-size fits all" rule prevails. In Europe and particularly in Italy, a costly and complex regulation enhances a consolidation process in banking and an increase of finance-based transactions. ${ }^{14}$ There is an apparent contradiction between the policy of banking consolidation and retrenchment and the objectives of financial stability and economic development.

\footnotetext{
13 See the Fed's president Yellen (2014), that expressed: "The concern that overly complex accounting rules in this area would increase costs with little benefit for the users of community banks financial statements" and consequently admitted the need of a "tailored supervision of community banks".

14 See the speech by the Governor of Bank of Italy Visco at "Giornata mondiale del risparmio", Rome, October 25, 2015.
} 
The "too-small-to-survive" fall-out for small banks, a consequence of uniform regulation, goes hand in hand with the reinforcement of the "too-big-to-fail" protection for big banks. Is it true that fewer and bigger banks will create a less risky system than a mixture of large and small banks? The GFC lesson seems to indicate otherwise. It originated in large multinational banks, where financial creativity was most advanced. Only in its second wave the weaknesses of commercial banking manifested themselves and those were mostly the result of the economic crisis. But the rapid increase of nonperforming loans cannot be attributed to bank size. Commercial banking, especially community banking, fell victim first to a bad economy and later to the policy of fiscal austerity that kept depressed aggregate demand. Bank loans fell in quantity demanded and deteriorated in quality. A bad economy, lower collateral values, optimistic credit evaluations, and bank mismanagement contributed to the rise of non-performing loans, Italy being a prime example of this state of affairs. While we do not have a precise breakdown of the relative contributions of each factor, a bad economy looms as the significant driver underlying non-performing loans. The negative effects of the latter on profitability were aggravated by an erosion of intermediation margins; on these the zero-rate monetary policy played its role.

Bank losses produced two contrasting forces. The first was an erosion of banks' safety driven by lower profitability. The new regulatory regime, with its attendant costs, contributed to the decline in banks' earnings. The second was the reaction of regulators who wanted banks to raise fresh capital to buttress safety. But here comes the conundrum. How can regulation raise bank safety through higher capitalization in a world where banks are perceived to be less profitable and riskier? While investors demand a higher required return on capital, banks' performance is incapable of satisfying these demands. In sum, it is hard to make the case that community and regional banks have been the great villain in the crisis.

Moving to economic development, the noted asymmetric burden of regulation on banking structure produces related asymmetries on firms and regional economies. Small firms and peripheral regions are highly dependent on bank credit and need strategic proximity of banking structures. The reviewed empirical evidence demonstrates that larger and more (functionally) distant banks penalize small firms, which are more opaque and more exposed to credit rationing. The objective of shifting some bank intermediation to financial markets will affect disproportionately smaller firms, whose characteristics are not congruent with the issue of negotiable debt instruments. While one cannot discount the role innovations, such as mini bonds, that may be suitable to small firms, the point remains that the adoption of a regulatory system that penalizes small banks' credit function to stimulate market-based financing is not only inadequate, but also distorting. One likely prediction is that the industrial structure of the country (Italy in particular) will have to change as a result of the shift in emphasis from bank to finance intermediation. Firm size will have to adapt to the available financing 
options. Smaller firms will not survive and industrial structure will move towards larger firms. Furthermore, regions as well will be affected asymmetrically by the uniform regulation. The less developed regions of a country tend to have a higher proportion of small, riskier firms, that have a higher consumption of bank capital. It follows that bank credit is more rationed in less developed areas than in developed areas. In sum, the asymmetric impact of uniform regulation is likely to change industrial structure to different degrees across regions. It may well be that this is the ultimate objective of regulatory policy. If so, the authorities ought to be plain on what they aim and their consequences.

Finally, our review of the literature on different countries and on different periods of time, including the GFC years, suggests the importance of a differentiated banking model when firms and regions are heterogeneous. There is no obvious optimal size of bank. Bank organization and governance must be evaluated in relative terms, according to criteria such as: types of banks involved in M\&As, functional distance, opacity of local market information, regional development disparities, and territorial sensibility by bank management. Therefore, it is wise for a regulatory system not to favor one particular bank size. The market should decide on this size, whereas the authorities should concentrate on the reconciliation of market efficiency with financial stability and limit the swing of the pendulum between the two extremes of full liberalization and oppressive regulation. Our preferred policy is for a dual-regulatory system that would achieve a more symmetric distribution of the regulatory burden. The United States has moved in this direction, the European Union not. ${ }^{15}$ It is odd that a country where small firms and bank credit are less relevant than in Europe has opted for a dual approach. It is equally odd that the importance of preserving local banks is valued less in Italy than in Germany.

\section{References}

Aghion, Philippe and Jean Tirole. 1997. Formal and real authority in organizations, Journal of Political Economy 105(1): 1-29.

Alonso, Ricardo, Wouter Dessein and Niko Matouschek. 2008. When does coordination require centralization?, American Economic Review 98(1):145-179.

Alessandrini, Pietro, Luca Papi and Alberto Zazzaro. 2003. Banks, regions and development, BNL Quarterly Review, 56(224):23-55.

Alessandrini, Pietro, Manuela Croci and Alberto Zazzaro. 2005. The geography of banking power: the role of functional distances. BNL Quarterly Review, 58(235):129-167.

\footnotetext{
15 Again it is worth quoting Yellen's remarks: "I believe a healthy financial system relies on institutions of different sizes performing a variety of functions and serving different needs" (Yellen, 2014).
} 
Alessandrini, Pietro, Giorgio Calcagnini and Alberto Zazzaro. 2008. Asset restructuring strategies in bank acquisitions: Does distance between dealing partners matter?. Journal of Banking and Finance 32(5): 699-713.

Alessandrini, Pietro, Andrea F. Presbitero and Alberto Zazzaro. 2009a. Global banking and local markets: A national perspective. Cambridge Journal of Regions Economy and Society 2(2): 173-192.

Alessandrini, Pietro, Andrea F. Presbitero and Alberto Zazzaro. 2009b. Banks, distances and firms' financing constraints, Review of Finance 13(2): 261-307.

Alessandrini, Pietro, Andrea F. Presbitero and Alberto Zazzaro. 2010. Bank size or distance: What hampers innovation adoption by SMEs?, Journal of Economic Geography 10(6):845-881.

Angelini, Paolo, Giovanni Ferri and Valerio Vacac. 1997. Banche e sviluppo economico in Italia: Un'analisi a livello comunale. In Credito e sviluppo, edited by F. Cesarini, G. Ferri and M. Giardino. Bologna: il Mulino, 131-150.

Avery, Robert B. and Katherine A. Samolyk. 2004. Bank consolidation and small business lending: The role of community banks. Journal of Financial Services Research 25(2): 291-325.

Berger, Allen N. and Lamont K. Black. 2011. Bank size, lending technologies, and small business finance. Journal of Banking and Finance 35(3):724-735.

Berger, Allen N., Rebecca S. Demsetz and Philip E. Strahan. 1999. The consolidation of the financial services industry: Causes, consequences, and implications for the future. Journal of Banking and Finance 23(2-4):135-94.

Berger, Allen N. and Robert DeYoung. 2006. Technological progress and the geographic expansion of the banking industry. Journal of Money, Credit and Banking 38(6 Supplement): 1483-1513.

Berger, Allen N. and Robert De Young. 2006. Technological progress and the geographic expansion of the banking industry. Journal of Money, Credit and Banking 38(6 Supplement): 1483-1513.

Berger, Allen N., Iftekhar Hasan \& Leora Klapper. 2004. Further evidence on the link between finance and growth: An international analysis of community banking and economic performance. Journal of Financial Services Research 25(2):169-202.

Berger, Allen N., Anil K. Kashyap and Joseph M. Scalise. 1995. The transformation of US banking industry: What a long, strange trip it's been”, Brookings Papers on Economic Activity. 2:55-218.

Berger, Allen N., Nathan H. Miller, Mitchell A. Petersen, Raghuram G. Rajan and Jeremy C. Stein. 2005. Does function follow organizational form? Evidence from the lending practices of large and small banks. Journal of Financial Economics. 76(1):237-269.

Berger, Allen N., Richard J. Rosen and Gregory F. Udell. 2007. Does market size structure affect competition? The case of small business lending. Journal of Banking and Finance 31(1):11-33.

Berger, Allen N., Anthony Saunders Joseph M. Scalise and Gregory F. Udell. 1998. The effects of bank mergers and acquisitions on small business lending. Journal of Financial Economics 50(2):187-229. 
Berger, Allen N. and Gregory F. Udell. 1998. The economics of small business finance: The roles of private equity and debt markets in the financial growth cycle. Journal of Banking and Finance 22(68):613-73.

Berrospide, Jose M., Lamont K. Black and William R. Keeton. 2013. The cross-market spillover of economic shocks through multi-market banks. Federal Reserve Board, Finance and Economics Discussion Series 2013-52.

Bonaccorsi, Emilia and Giorgio Gobbi. 2001. The changing structure of local credit markets: are small businesses special?. Journal of Banking and Finance 25(12):2209-2237.

Bonaccorsi, Emilia and Giorgio Gobbi. 2007. Winners or losers? The effects of banking consolidation on corporate borrowers. Journal of Finance 62(2):669-695.

Campello, Murillo. 2002. Internal capital markets in financial conglomerates: Evidence from small bank responses to monetary policy. Journal of Finance 57(6):2773-805.

Caprio, Gerard, Jr. 2013. Financial regulation after the crisis: How did we get here, and how do we get out?, LSE Financial Market Group Special Paper Series N. 226, November.

Carlin, Wendy, Andrew Charlton and Colin Mayer. 2006. Capital markets, ownership and distance. CEPR Discussion Papers 5764.

Cecchetti, Stephen and Enisse Kharroubi. 2012. Reassessing the impact of finance on growth. BIS Working Paper 381.

Cecchetti, Stephen and Enisse Kharroubi. 2015. Why Does Financial Sector Growth Crowd Out Real Growth? CEPR Working Paper 10642.

Cetorelli, Nicola and Linda Goldberg. 2012a. Liquidity management of U.S. global banks: Internal capital markets. Journal of International Economics 88(2):299-311.

Cetorelli, Nicola and Linda Goldberg. 2012a. Banking globalization and monetary transmission. Journal of Finance 67(5):1811-1843.

Claessens Stijn and Neeltje Van Horen. 2014b. Foreign banks: Trends and impact. Journal of Money, Credit and Banking 46(s1):295-326.

Cline, William R. 2015. Testing the Modigliani-Miller theorem of capital structure irrelevance for banks, Peterson Institute for International Economics WP 15-8.

Cole, Rebel A., Lawrence G. Goldberg and Lawrence J. White. 2004. Cookie-cutter versus character: The micro structure of small business lending by large and small banks. Journal of Financial and Quantitative Analysis 39(2):227-251.

Collender, Robert N. and Sherrill Shaffer 2003. Local bank office ownership, deposit control, market structure, and economic growth. Journal of Banking and Finance 27(1):27-57.

Cosci, Stefania and Fabrizio Mattesini. 1997. Credito e sviluppo nelle province italiane. In Credito e sviluppo, edited by F. Cesarini, G. Ferri and M. Giardino. Bologna: il Mulino, 89-130. 
Cournède, Boris and Oliver Denk. 2014. Finance and economic growth in OECD and G20 countries. OECD Economics Department Working Paper 1223.

Cremers, K. J. Martijn, Rocco Huang and Zacharias Sautner. 2010. Internal capital markets and corporate politics in a banking group. Review of Financial Studies 24(2):358-401.

Degryse, Hans, Nancy Masschelein and Janet Mitchell. 2011. Staying, dropping, or switching: The impacts of bank mergers on small firms. Review of Financial Studies 24 (4):1102-1140.

De Haas, Ralph and Neeltje Van Horen. 2013. Running for the Exit: International Banks and Crisis Transmission." Review of Financial Studies 26(1):244-85.

Dekle, Robert and Mihye Lee. 2015. Do foreign bank affiliates cut their lending more than the domestic banks in a financial crisis?. Journal of International Money and Finance 50(1):16-32.

Demma Cristina. 2015. Localismo bancario e crisi finanziaria, Banca d'Italia, Questioni di Economia e Finanza 264.

Detragiache, Enrica, Thierry Tressel and Poonam Gupta, P., 2008, Foreign banks in poor countries: Theory and evidence, Journal of Finance 63(5):2123-2160.

Dessein, Wouter 2002. Authority and communications in organizations, Review of Economic Studies 69(4):811-838.

DeYoung, Robert, Dennis Glennon and Peter Nigro. 2008. Borrower-lender distance, credit scoring, and loan performance: evidence from informational-opaque small business borrowers. Journal of Financial Intermediation 17(1):113-143.

Ductor, Lorenzo and Daryna Grechyna. 2013. Financial development, technological progress and economic growth. Working paper http://papers.ssrn.com/sol3/papers.cfm?abstract id=1997526.

Easterly, William Roumeen Islam and Joseph E. Stiglitz. 2000. Shaken and Stirred: Explaining Growth Volatility, in Annual World Bank Conference on Development Economics 2000, edited by B. Pleksovic and N. Stern, 191-211.

European Systemic Risk Board. 2014. Is Europe overbanked? Reports of the Advisory Scientific Committee, 4.

Ferri, Giovanni and Fabrizio Mattesini.1997. Finance, human capital and infrastructure: an empirical investigation on postwar Italian growth. Bank of Italy Working Papers (Temi di discussion) 321.

Financial Stability Board. 2014. Adequacy of loss-absorbing capacity of global systematically important banks in resolution: consultative document, November.

Financial Stability Board. 2015. 2015 update of list of global systematically important banks (G-SIBs), 3 November.

Filomeni, Stefano, Gregory F. Udell and Alberto Zazzaro. 2016. Hardening Soft Information: How Far Has Technology Taken Us?. Working Paper.

Focarelli, Dario, Fabio Panetta and Carmelo Salleo 2002. Why Do Banks Merge?. Journal of Money, Credit and Banking 34(4):1047-1066. 
Fratianni, Michele and Franco Spinelli. 2001. Storia monetaria d'Italia: Lira e politica monetaria dall'Unità all'Unione Europea. Milano: Etas.

Fratianni, Michele and John Pattison. 2002. International Financial Architecture and International Financial Standards, Annals, AAPSS (Annals of The American Academy of Political and Social Science), 579, January 2002: 183-199.

Fratianni, Michele. 2015. Basel III in reality. Journal of Economic Integration 30(1):1-28.

Galli, Giampaolo and Marco Onado. 1990. Dualismo territoriale e sistema finanziario. In Il sistema finanziario nel Merzogiorno, edited by G. Galli. Special issue of Contributi all'analisi economica, Roma: Banca d'Italia.

Gambacorta, Leonardo and Paolo E. Mistrulli. 2014. Bank heterogeneity and interest rate setting: What lessons have we learned since Lehman Brothers?. Journal of Money, Credit and Banking 46(4):753778.

Giannetti, Mariassunta and Luc Laeven. 2011. The flight home effect: Evidence from the syndicated loan market during financial crises. Journal of Financial Economics 104(1):23-43.

Giannetti, Mariassunta and Yishay Yafeh. 2012. Do cultural differences between contracting parties matter? Evidence from syndicated bank. Management Science 58(2):365-383.

Giannola, Adriano. 2002. Il credito difficile. Napoli: L'ancora del mediterraneo.

Gobbi, Giorgio and Enrico Sette. 2015. Relationship lending during a financial crisis. Journal of the European Economic Association 13(3):453-481.

Goldsmith, Raymond W. 1969. Financial structure and development. New Haven: Yale University Press.

Gormley, Todd A. 2010. The impact of foreign bank entry in emerging markets: Evidence from India. Journal of Financial Intermediation 19(1):26-51.

Hakenes Hendrik, Iftekhar Hasan, Philip Molyneux and Ru Xie. 2015. Small banks and local economic development. 19(2):653-683.

Haldane, Andrew G. 2011. Capital discipline, speech at the American Economic Association, Denver, Colorado, $9^{\text {th }}$ of January.

Hertzberg, Andrew, Josè M. Liberti and Daniel Paravisini. 2010. Information and incentives inside the firm: Evidence from loan officer rotation. Journal of Finance 65(3):795-828.

Houston, Joel F. and Christopher James. 1998. Do bank internal capital markets promote lending?. Journal of Banking and Finance 22(6-8):899-918.

Houston, Joel F., Christopher James and Davis Marcus. 1997. Capital market frictions and the role of internal capital markets in banking", Journal of Financial Economics, 46(2):135-64.

Hunter, Maryann F. 2015. Statement before the Subcommittee on Financial Institutions and Consumer Credit, U.S. House of Representatives, April 23.

Imai, Masami and Seitaro Takarabe. 2011. Bank integration and transmission of financial shocks: 
Evidence from Japan. American Economic Journal: Macroeconomics 3(1):155-83.

Jayaratne, Jith and Philip E. STRAHAN. 1996. The finance-growth nexus: evidence from bank branch deregulation. Quarterly Journal of Economics 111(3):639-71.

Koch, Christoffer. 2013. Regulatory burden rising, in Federal Reserve Bank of Dallas, Financial stability: Traditional banks pave the way.

Laeven, Luc, Ratnovski Lev and Hui Tong. 2014. Bank size and systemic risk, IMF Staff Discussion Note N. SDN/14/04.

Landier, Augustin, Vinay B. Nair and Julie Wulf. 2009. Trade-offs in staying close: corporate decision making and geographic dispersion. Review of Financial Studies, 22(3): 1119-1148.

Law, Siong H. and Nirvikar Singh. 2014. Does too much finance harm economic growth? Journal of Banking and Finance 41(April): 36-44.

Levine, Ross. 2005. Finance and growth: Theory and evidence, in Handbook of economic growth vol. $1 \mathrm{~A}$, edited P. Aghion and S. Durlauf. Amsterdam: Elsevier, 865-934.

Lucchetti, Riccardo, Luca Papi and Alberto Zazzaro. 2001. Banks' inefficiency and economic growth: A micro-macro approach", Scottish Journal of Political Economy 48(4):400-24.

Liberti, Jose M. and Atif R. Mian. 2009. Estimating the effect of hierarchies on information use. Review of Financial Studies 22(10):4057-4090.

Masera, Rainer. 2015. Regole e supervisione delle banche: approccio unitario vs modello per livelli e implicazioni per la morfologia del sistema delle banche, EU e US. Working paper 30 Novembre, Università degli Studi Guglielmo Marconi.

Meyer, Margaret, Paul Milgrom and John Roberts. 1992. Organizational prospects, influence costs and ownership changes, Journal of Economics and Management Strategy 1(1):9-35.

Mian, Atif. 2006. Distance constraints: The limits of foreign lending in poor economies. Journal of Finance 61(3):1465-1505.

Modigliani, Franco and Merton H. Miller. 1958. The cost of capital, corporation finance and the theory of investment, American Economic Review 48(3):261-297.

O'Brien, Richard. 1992. Global financial integration: The end of geography. London: Royal Institute of International Affairs.

Ogura, Yoshiaki and Hirofumi Uchida. 2014. Bank consolidation and soft Information acquisition in small business lending Journal of Financial Services Research 45(2):173-200.

Pagano, Marco and Giovanni Pica. 2012. Finance and employment. Economic Policy, 27(69):5-55.

Peek, Joe and Eric S. Rosengren.1998. Bank consolidation and small business lending: it's not just bank size that matters, Journal of Banking and Finance 22(6-8):799- 819.

Peek, Joe and Eric S. Rosengren. 1997. The international transmission of financial shocks: The case of Japan. American Economic Review 87(4):495-505. 
Peek, Joe and Eric S. Rosengren. 2000. Collateral damage: Effects of the Japanese bank crisis on real activity in the United States. American Economic Review, 90(1): 30-45.

Petersen, Mitchell A. and Raghuram G. Rajan. 2002. Does distance still matter? The information revolution in small business lending. Journal of Finance, 57(6): 2533-2570.

Persaud, Avinash D. 2014. Why bail-in securities are fool's gold, Peterson Institute for International Economics, Policy Brief N. PB14-23.

Presbitero, Andrea F. and Alberto Zazzaro. 2011. Competition and relationship lending: Friends or foes?. Journal of Financial Intermediation 20(3):387-413.

Presbitero, Andrea F., Gregory F. Udell and Alberto Zazzaro. 2014. Competition and relationship lending: Friends or foes?. Journal of Money, Credit and Banking 46(s1):53-85.

Popov Alexander and Gregory F. Udell Cross-border banking, credit access, and the financial crisis. Journal of International Economics 87(1):147-161.

Rioja, Felix \& Valev, Neven, 2004. Does one size fit all? A reexamination of the finance and growth relationship. Journal of Development Economics. 74(2): 429-447.

Robinson, Joan. 1952. The generalization of the General Theory, in The rate of interest and other essays, edited by J. Robinson. London: Macmillan, 67-142.

Rousseau, Peter L. and Paul Wachtel. 2011. What is happening to the impact of financial deepening on economic growth?. Economic Inquiry, 49(1): 276-288.

Sapienza, Paola. 2002. The effects of banking mergers on loan contracts. Journal of Finance 57(1):329-67.

Scharfstein David S. and Jeremy C. Stein. 2000), "The dark side of internal capital markets: divisional rent-seeking and inefficient investment", Journal of Finance, 55(6):2537-64.

Schnabl, Philipp. 2012. The international transmission of bank liquidity shocks: Evidence from an emerging market.” Journal of Finance 67(3):897-932.

Schumpeter, Joseph A. 1934. The theory of economic development. New York: Oxford University Press.

Scott, Jonathan A. 2004. Small business and the value of community financial institutions. Journal of Financial Services Research 25(2/3):207-230.

Siegert, Caspar and Matthew Willison. 2015. Estimating the extent of the 'too big to fail' problem - a review of existing approaches, Bank of England, Financial Stability Paper, 32.

Stefani Maria Lucia, Valerio Vacca, Daniele Coin, Silvia Del Prete, Cristina Demma, Maddalena Galardo, Iconio Garrì, Sauro Mocetti, Dario Pellegrino. 2016, Le banche locali e il finanziamento dei territori: Evidenze per l'Italia (2007-2014). Banca d'Italia, Questioni di Economia e Finanæa. 324.

Stein, Jeremy C. 2002. Information production and capital allocation: Decentralized versus hierarchical firms.” Journal of Finance 57(5): 1891-921.

Strahan, Philip E. and James P. Weston. 1998. Small business lending and the changing structure of the banking industry. Journal of Banking and Finance, 22(6-8):821- 45. 
Tobin, James. 1984. On the efficiency of the financial system. Lloyds Bank Review 153:1-15.

Uchida, Hirofumi, Gregory F. Udell and Wako Watanabe. 2012. Bank size and lending relationships in Japan," Journal of the Japanese and International Economies 22(2):242-267.

Uchida, Hirofumi, Gregory F. Udell and Nobuyoshi Yamori. 2012. Loan officers and relationship lending to SMEs, Journal of Financial Intermediation 21(1): 97-122.

Udell, Gregory F. 1989. Loan quality, commercial loan review and loan officer contracting. Journal of Banking and Finance 13(3): 367-382.

Usai, Stefano and Marco Vannini. 2005. Banking structure and regional economic growth: Lessons from Italy. Annals of Regional Science 39(4):691-714.

White, Eugene N. 1986. Before the Glass-Steagall Act: An analysis of the investment activities of national banks, Explorations in Economic History 23(1): 33-55.

Yellen, Janet L. 2014. Tailored supervision of community banks, Remarks made at Policy Summit of the Independent Community Bankers of America, Washington, May 1.

Zazzaro, Alberto. 2006. La scomparsa dei centri decisionali dal sistema bancario meridionale. Rivista di Politica Economica 3-4:31-60. 